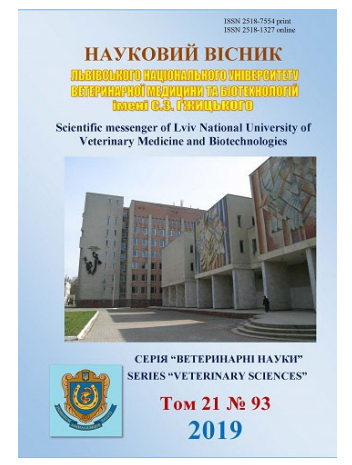

\author{
Науковий вісник Дьвівського національного університету \\ ветеринарної медицини та біотехнологій імені С.З. Гжицького. \\ Серія: Ветеринарні науки \\ Scientific Messenger of Lviv National University \\ of Veterinary Medicine and Biotechnologies. \\ Series: Veterinary sciences
}

\title{
Dynamics of changes in protein metabolism rates in cows depending on the season of the year and the location of the farm
}

\author{
U.M. Vus, O.V. Kozenko \\ Stepan Gzhytskyi National University of Veterinary Medicine and Biotechnologies Lviv, Ukraine
}

Article info

Received 14.02.2019

Received in revised form 15.03.2019

Accepted 18.03.2019

Stepan Gzhytskyi National University of Veterinary Medicine and Biotechnologies Lviv, Pekarska Str., 50, Lviv, 79010, Ukraine. Tel.: +38-067-747-05-25 E-mail: ulyanavus@gmail.com
Vus, U.M., \& Kozenko, O.V. (2019). Dynamics of changes in protein metabolism rates in cows depending on the season of the year and the location of the farm. Scientific Messenger of Lviv National University of Veterinary Medicine and Biotechnologies. Series: Veterinary sciences, 21(93), 164-168. doi: 10.32718/nvlvet9329

Protein metabolism in animals is perhaps the most informative indicator of anthropogenic environmental pollution, because it provides an opportunity to characterize metabolic processes in the body. They are of the utmost importance for the structure and function of all cells, tissues and organs. Proteins reflect the state of the organism, as well as those changes that occur in it under the influence of internal and external factors. We studied the dynamics of changes in indicators in protein metabolism in cows depending on the season of the year and the location of a farm. The research was carried out in two farms of the Lviv region: the Danylo Halytskyj LLC, near the State Mining and Chemical Enterprise "Sirka", and FE "Lelyk" of Zhovkva district, in spring, summer, autumn and winter periods of keeping. The object of research was the blood of 20 cows of Ukrainian Black-Spotted breed. According to the results of the research, a reduction in total protein, relative to the physiological norm of $0.45 \mathrm{~g} / \mathrm{l}$. in spring, and by $0.64 \mathrm{~g} / \mathrm{l}$ in the summer, dysproteinemia, a high level of gamma globulin fraction (50.30\%) in cows from the Danylo Halytskyj farm, located in the zone of influence of the State Chemical Medicine Plant "Sirka". In animals FE Lelyk, located in the conventionally clean zone, this indicator was significantly higher, and was $76.14 \mathrm{~g} / \mathrm{l}$ in spring, and $78.17 \mathrm{~g} / \mathrm{l}$ in summer, and also in animals of this farm dysproteinemia was not observed. In the autumn, at the end of the summer grazing period of the keeping, the index of total protein tended to decrease in the animals of the Danylo Halytsky's Ltd., and in winter it was normalized and invested in the limits of the physiological norm. Albumin fraction of protein in this group of animals, throughout the search period, had a tendency to increase. In the cows of the FE "Lelyk", the indices of protein metabolism were within the limits of the physiological norm in all periods of research, with the inherent fluctuations in the season of the year. The obtained results due to the content of total protein and protein fractions in the plasma of blood of cows kept in territories with different ecological status indicate that the effect of the activity of the State Chemical Medicine Plant "Sirka" is sufficiently strong on the organism of animals.

Key words: cows, search periods, total protein, protein fractions, ecological conditions.

\section{Динаміка змін показників білкового обміну в корів залежно від сезону року та території розташування господарства}

\author{
У.М. Вус, О.В. Козенко \\ Львівський національний університет ветеринарної медицини та біотехнологій імені С.3. Гжиџького, \\ м. Львів, Украӥна
}

Білковий обмін у тварин є чи не найбільи інформативним показником при техногенному забрудненні середовища, оскільки дає можливість охарактеризувати обмінні процеси в організмі. Вони мають винятково важливе значення для будови та функціонування всіх клітин, тканин і систем органів. Білки відображають стан організму, а також ті зміни, які в ньому відбуваються під впливом внутрішніх та зовнішніх чинників. Вивчали динаміку змін показників білкового обміну у корів залежно від сезону року та 
території розташування господарства. Дослідження були проведені в двох господарствах Львівської області: ТзОВ імені Данила Галищького, поблизу Державного гірничо-хімічного підприємства “Сірка”, та ФГ “Лелик” Жовківського району у весняний, літній, осінній та зимовий періоди утримання. Об'єктом досліджень була кров 20 корів української чорно-рябої породи. Згідно з одержаними результатами досліджень встановлено зниження загального білка, щуодо фізіологічної норми на 0,45 г/л у весняний, та на 0,64 г/л у літній періоди, диспротеїнемію, високий рівень гама глобулінової фракиї (50,30\%) у корів з господарства імені Данила Галицького, розташованого в зоні впливу ДГХП “Сірка”. У тварин ФГ “Лелик”, розташованого в умовно чистій зоні, ией показник був значно більшим і становив 76,14 г/л весною та 78,17 г/л влітку, також у тварин иьього господарства диспротеїнемї не спостерігалось. Восени, по закінченні літнього пасовищного періоду утримання, показник загального білка мав тенденцію до зниження у тварин ТзОВ імені Данила Галицького, а взимку нормалізувався і вкладався в межі фізіологічної норми. Альбумінова фракиія білка у цієї групи тварин впродовж усього періоду досліджень мала тенденцію до зростання. У корів ФГ “Лелик” показники білкового обміну перебували в межах фізіологічної норми в усі періоди досліджень, з притаманними щзодо сезону року коливаннями. Одержані результати щодо вмісту загального білка та білкових фракцій у плазмі крові корів, яких утримують на територіях з різним екологічним статусом, вказують на достатньо потужний вплив на організм тварин наслідків діяльності ДГХП “Сірка”.

Ключові слова: корови, періоди дослідження, загальний білок, білкові фракції, екологічні умови.

\section{Ветуп}

Сучасні екологічні умови довкілля негативно впливають на всі його складові і в першу чергу на життєздатність тварин. Сьогоднішня екологічна ситуація у Львівській області має проблеми, породжені десятками років тому (Petrovska, 2011). Відтак перспективи поліпшення стану довкілля нині залежать не стільки від наміру вживати природоохоронні заходи, скільки від реальних можливостей ліквідації наслідків уже завданих екологічних збитків. На іiі території розташовано понад 840 промислових підприємств, у тому числі з видобутку нафти, вугілля та сірки. Непростою була і залишається ситуація у Яворівському районі, в зоні впливу ДГХП “Сірка”. Хоча видобування сірки припинено в 1998 році, але на даний час залишається проблема наявності важких металів у хвостосховищах промислових розробок (Dobrzanski et al., 1996; Stezhka et al., 2003).

Доведено, що великі промислові об'єкти здатні забруднювати довкілля на десятки кілометрів. Виробничі викиди останніх у ряді випадків можуть привести до створення штучних, локальних біогеохімічних провінцій, які займають значні території. На відміну від органічних сполук токсичні метали не руйнуються у грунті та воді, а нагромаджуються і мігрують трофічними ланцюгами в організм тварин і людей у значних кількостях. Нагромадження їх у тканинах і органах сільськогосподарських тварин негативно впливає на імунологічний статус, ферментні системи, репродуктивну функцію організму, термін господарського використання. Внаслідок цього наприкінці XX i на початку XXI століття відбувається значне погіршення стану здоров'я і збільшується кількість захворювань (Butsiak \& Kravtsiv, 2003; Salvatori et al., 2004; Kravtsiv et al., 2004; Kravtsiv et al., 2009; Gutyj, 2015; Hradovych et al., 2016; Hutyi et al., 2016; Vishchur et al., 2016; Khariv et al., 2016; Gutyj et al., 2017; Gutyj et al., 2019).

Білковий обмін у тварин є чи не найбільш інформативним показником при техногенному забрудненні середовища, оскільки дає можливість охарактеризувати обмінні процеси в організмі. Вони мають винятко- во важливе значення для будови та функціонування всіх клітин, тканин і систем органів. За різних фізіологічних станів та при токсичних ураженнях організму співвідношення між фракціями білків сироватки крові змінюється: кількість окремих білкових фракцій знижується, а інших - підвищується. Враховуючи вищесказане, метою роботи було дослідити фракційний склад білків у корів з різних в екологічному плані зонах та сезонах року (Lazarenko \& Melnykova, 2012).

\section{Матеріал і методи досліджень}

Дослідження проводили у двох господарствах Львівської області: ТзОВ імені Данила Галицького поблизу ДГХП “Сірка” Яворівського району та ФГ “Лелик” Жовківського району, розташованого в умовно чистій екологічній зоні. Об'єктом досліджень була кров 20 корів української чорно-рябої породи, взята 3 яремної вени вранці до годівлі з дотриманням правил асептики та антисептики. Визначали рівень загального білка плазми крові рефрактометричним методом (RL-2), співвідношення білкових фракцій за методом Олла і Маккорда в модифікації Карпюка у зимовий, весняний, літній та осінній періоди утримання (Kondrahin et al., 1985; Shevchenko et al., 2004; Vlizlo et al., 2004). Отримані числові дані обробляли статистично з використанням комп'ютерної програм. Результати середніх значень вважали статистично вірогідними при $\mathrm{P}<0,05-*$; $\mathrm{P}<0,02-* * ; \mathrm{P}<0,01-$ $* * * ; \mathrm{P}<0,001-* * * *$.

\section{Результати та їх обговорення}

Білки є досить лабільною системою, що відображає стан організму, а також ті зміни, які в ньому відбуваються під впливом внутрішніх та зовнішніх чинників. Дуже часто зміна хімічного складу зовнішнього середовища спричиняє зміну білкового складу крові тварин (Butsiak et al., 2006).

Результати досліджень протеїнограми плазми крові корів з обох господарств у весняний та літній період утримання наведені в таблиці 1. 
Таблиця 1

Протеїнограма плазми крові корів у весняний та літній періоди (M \pm m, n = 10)

\begin{tabular}{|c|c|c|c|c|}
\hline \multirow[b]{2}{*}{ Показники } & \multicolumn{2}{|c|}{ Весна } & \multicolumn{2}{|c|}{ Літо } \\
\hline & $\begin{array}{c}\text { ТзОВ імені Данила } \\
\text { Галицького }\end{array}$ & ФГ “Лелик” & $\begin{array}{c}\text { ТзОВ імені Данила } \\
\text { Галицького }\end{array}$ & ФГ “Лелик” \\
\hline Загальний білок, г/л & $69,55 \pm 1,07$ & $76,14 \pm 0,68^{* * * * *}$ & $69,36 \pm 0,58$ & $78,17 \pm 1,29 * * * *$ \\
\hline Альбуміни, \% & $32,02 \pm 0,14$ & $41,25 \pm 0,17 * * * *$ & $34,80 \pm 0,35$ & $45,88 \pm 1,06^{* * * *}$ \\
\hline$\alpha$-глобуліни, \% & $9,76 \pm 0,14$ & $13,18 \pm 0,08 * * * *$ & $19,22 \pm 0,63$ & $18,86 \pm 0,33$ \\
\hline$\beta$-глобуліни, \% & $7,92 \pm 0,13$ & $15,62 \pm 0,17 * * * *$ & $7,28 \pm 0,14$ & $10,80 \pm 1,01 * * *$ \\
\hline$\gamma$-глобуліни, \% & $50,30 \pm 0,35$ & $29,95 \pm 0,17 * * * *$ & $38,70 \pm 0,66$ & $24,46 \pm 1,01 * * * *$ \\
\hline $\mathrm{A} / \Gamma$ & $0,47 \pm 0,003$ & $0,70 \pm 0,005^{* * * *}$ & $0,54 \pm 0,004$ & $0,85 \pm 0,003 * * * *$ \\
\hline
\end{tabular}

Згідно з одержаними результатами, наведеними у таблиці 1, у корів з господарства імені Данила Галицького, розташованого в зоні впливу ДГХП “Сірка”, встановлено низький показник вмісту загального білка, щодо фізіологічної норми та диспротеїнемію. Так, у цих тварин у весняний період вміст загального білка був на рівні дещо меншому за нижню межу фізіологічної норми і становив 69,55 г/л.

У літній період цей показник ще незначно зменшився і був на 0,64 г/л меншим за нижню межу фізіологічної норми, тимчасом як у тварин з ФГ “Лелик”, розташованого в умовно чистій зоні, рівень загального білка був значно більшим на 6,59 г/л та 8,81 г/л у весняний та літній періоди відповідно. Треба наголосити, що у тварин цього господарства диспротеїнемії не спостерігалось.

Дослідження білкових фракцій має вагоме значення, адже дає змогу виявити наявність патологічних процесів в організмі. У корів 3 ТзОВ імені Данила Галицького вміст альбумінової фракції білка був значно меншим на 7,98\% за нижню межу фізіологічної норми у весняний період. У літній період альбумінова фракція білка зросла на 2,78\%, проте не досягла нижнього рівня фізіологічної норми. Своєю чергою вміст альбумінів в плазмі крові корів з ФГ “Лелик”, був у межах фізіологічної норми і перевищував іiі нижню межу на 1,25 та 5,88\% відповідно у весняний і літній періоди.

Стосовно глобулінових фракцій, то у тварин 3 ТзОВ імені Данила Галицького у весняний період кількість $\alpha$-глобулінів була на $0,24 \%$ менша за нижню межу фізіологічної норми, а бета глобулінів - на 0,08\%. У літній період утримання цих тварин встановлено зростання $\alpha$-глобулінової фракції білка на 9,46\%, що ближче до верхньої межі фізіологічної норми.

Бета глобулінова фракція у літній період, має тенденцію до зниження і була на $0,64 \%$ меншою за весняний період. У корів з ФГ “Лелик” ці фракції білка були значно більшими порівняно з ровесницями зони вПливу ДГХП “Сірка” і перебували у межах фізіологічної норми, ближче до ії верхньої межі. Зокрема, альфаглобулінова фракція була на 3,42\% більшою у весняний період, проте на 0,36\% меншою у літній період, тимчасом як $\beta$-глобулінова фракція білка була значно вищою як у весняний, так і в літній періоди утримання.

При ураженні печінки часто спостерігають значне зростання $\gamma$-глобулінової фракції білка. Так, у тварин iз забрудненої зони у весняний період встановлено значне його зростання до 50,3\%, що на $10 \%$ більше за верхню межу фізіологічної норми. Влітку вміст цієї фракції знизився і був у межах норми, ближче до верхньої їі межі. У тварин із господарства, розташованого в умовно чистій екологічній зоні, $\gamma$ глобулінова фракція білка була в межах фізіологічної норми. Відповідав співвідношенню білкових фракцій і А/Г коефіцієнт.

Таблиця 2

Протеїнограма плазми крові корів у осінній та зимовий періоди $(\mathrm{M} \pm \mathrm{m}, \mathrm{n}=10)$

\begin{tabular}{lcccc}
\hline \multirow{2}{*}{ Показники } & \multicolumn{2}{c}{ Осінь } & \multicolumn{2}{c}{ Зима } \\
\cline { 2 - 5 } & $\begin{array}{c}\text { ТзОВ імені Данила } \\
\text { Галицького }\end{array}$ & \multirow{2}{*}{ ФГ “Лелик” } & $\begin{array}{c}\text { ТзОВ імені Данила } \\
\text { Галицького }\end{array}$ & \multirow{2}{*}{ ФГ “Лелик” } \\
\hline Загальний білок, г/л & $69,02 \pm 0,65$ & $73,82 \pm 1,47 * * * *$ & $72,46 \pm 0,43$ & $75,37 \pm 0,62^{* * *}$ \\
Альбуміни, \% & $35,24 \pm 0,18$ & $45,71 \pm 1,23 * * * *$ & $42,74 \pm 0,28$ & $42,12 \pm 0,23$ \\
$\alpha$-глобуліни, \% & $19,09 \pm 0,64$ & $19,09 \pm 0,27$ & $12,50 \pm 0,42$ & $16,14 \pm 0,16^{* * * *}$ \\
$\beta$-глобуліни, \% & $7,08 \pm 0,09$ & $10,65 \pm 0,95^{* *}$ & $6,83 \pm 0,26$ & $14,13 \pm 0,50^{* * * *}$ \\
$\gamma$-глобуліни, \% & $38,05 \pm 0,68$ & $24,55 \pm 1,63^{* * * *}$ & $37,93 \pm 0,19$ & $27,61 \pm 0,41^{* * * *}$ \\
А/Г & $0,54 \pm 0,004$ & $0,85 \pm 0,03$ & $0,75 \pm 0,009$ & $0,73 \pm 0,006$ \\
\hline
\end{tabular}

Згідно з таблицею 2, восени, по закінченню літнього пасовищного періоду вміст загального білка у корів ТзОВ імені Данила Галицького не зріс, а, навпаки, дещо знизився (на 0,34\%). Альбумінова фракція білка в цієї групи тварин протягом усього періоду дослідженнь, мала тенденцію до зростання. Восени вона становила $35,24 \%$, що на $0,44 \%$ більше за літній період. Найвищим цей показник був у зимовий період $(42,74 \%)$ і знаходився у межах норми. У ровесниць 3 ФГ “Лелик” вміст загального білка та альбумінової 
його фракції був значно вищим. Виняток становив зимовий період. Взимку альбумінова фракція білка була на $0,62 \%$ вищою.

Стосовно глобулінів - у тварин обох господарств в осінній і зимовий періоди спостерігалась певна тенденція до нормалізації цих показників. Альфа- глобулінова фракція білка восени у корів обох груп становила $19,09 \%$. Взимку відбулось певне зниження і різниця між групами становила 3,64\% на користь тварин 3 ФГ “Лелик”. У цих же тварин показник бетаглобулінової фракції білка і надалі перебував у межах фізіологічної норми, тимчасом як у корів 3 ТзОВ імені Данила Галицького він залишався доволі низьким.

Гама-глобулінова фракція у тварин із зони впливу ДГХП “Сірка”, восени, так і взимку мала тенденцію до зниження і становила в середньому $38 \%$. Альбуміново-глобулінове співвідношення теж мало тенденцію до нормалізації.

\section{Висновки}

Одержані результати щодо вмісту загального білка та білкових фракцій у плазмі крові корів, яких утримують на територіях з різним екологічним статусом, вказують, на достатньо потужний вплив на організм тварин наслідків діяльності ДГХП “Сірка”. Особливо вразливим організм цих тварин стає влітку, коли вони перебувають на пасовищі. В цей період у плазмі їхньої крові був найменший вміст загального білка, яскраво виражена диспротеїнемія та високий рівень гамаглобулінової фракції, що вказує на реакцію тривоги. У тварин з ФГ “Лелик” досліджувані показники плазми крові перебували в межах фізіологічної норми як улітку, так і в інші сезони року.

\section{References}

Butsiak, V.I., \& Kravtsiv, R.I. (2003). Vplyv tseolitiv na transformatsiiu vazhkykh metaliv orhanamy i tkanynamy koriv za umov antropohennoho navantazhennia. Biolohiia tvaryn, 5(1/2), 306-310 (in Ukrainian).

Butsiak, V.I., Kurliak, I.M., \& Butsiak, H.A. (2006). Profilaktychni zakhody shchodo vyrobnytstva ekolohichno-chystoho moloka u bioheokhimichnykh provintsiiakh. Problemy tekhnolohichnoho ta kadrovoho zabezpechennia v tekhnohennoekolohichnii sferi. Materialy mizhvuzivskoho naukovoho seminaru. Lviv, 3-12 (in Ukrainian).

Dobrzanski, Z., Kolacz, R., \& Bodak, E. (1996). Metale ciezkie w srodowisku zwierzat. MedycynaWeterynaryjna, 52(9), 570-574.

Gutyj, B., Nazaruk, N., Levkivska, A., Shcherbatyj, A., Sobolev, A., Vavrysevych, J., Hachak, Y., Bilyk, O., Vishchur, V., \& Guta, Z. (2017). The influence of nitrate and cadmium load on protein and nitric metabolism in young cattle. Ukrainian Journal of Ecology, 7(2), 9-13. doi: 10.15421/2017_14.

Gutyj, B.V. (2015). The activity of antioxidant protecting of the bulls for acute cadmium toxicosis. Scientific
Messenger of LNU of Veterinary Medicine and Biotechnologies, 17(1), 31-36. Retrieved from https://nvlvet.com.ua/index.php/journal/article/view/2 14.

Gutyj, B.V., Ostapyuk, A.Y., Sobolev, O.I., Vishchur, V.J., Gubash, O.P., Kurtyak, B.M, Kovalskyi, Y.V., Darmohray, L.M., Hunchak, A.V., Tsisaryk, O.Y., Shcherbatyy, A.R., Farionik, T.V., Savchuk, L.B., Palyadichuk, O.R., \& Hrymak, K. (2019). Cadmium burden impact on morphological and biochemical blood indicators of poultry. Ukrainian Journal of Ecology, 9(1), 236-239.

Hradovych, N., Paranyak, R., \& Zabytivskyi, Y. (2016). Influence of zeolites on lead and cadmium content in separate links of trophic chain in hydroecosystems. Scientific Messenger of LNU of Veterinary Medicine and Biotechnologies, 18, 2(67), 61-65. doi: $10.15421 /$ nvlvet6714.

Hutyi, B.V., Murska, S.D., Hufrii, D.F., Khariv, I.I., Levkivska, N.D., Nazaruk, N.V., Haidiuk, M.B., Pryima, O.B., Bilyk, O.Ia., \& Huta, Z.A. (2016). Vplyv kadmiievoho navantazhennia na systemu antyoksydantnoho zakhystu orhanizmu buhaitsiv. Visnyk Dnipropetrovskoho universytetu. Biolohiia, Ekolohiia, 24(1), 96-102. doi: 10.15421/011611 (in Ukrainian).

Khariv, M., Gutyj, B., Butsyak, V., \& Khariv, I. (2016). Hematological indices of rat organisms under conditions of oxidative stress and liposomal preparation action. Biological Bulletin of Bogdan Chmelnitskiy Melitopol State Pedagogical University. 6(1), 276-289. doi: 10.15421/201615.

Kondrahin, I.P., Kurilov, P.V., \& Malahov, A.G. (1985). Klinicheskaja laboratornaja diagnostika $\mathrm{v}$ veterinarii. Moskva. Agropromizdat (in Russian).

Kravtsiv, R.I., Kalyn, B.M., Fomina, M.V., \& Butsiak, H.A. (2009). Tekhnohennyi vplyv na ahroekosystemy ta yakist sils-kohospodarskoi produktsii. Naukovoteoretychnyi zhurnal Ahroekolohichnoi zhurnal, cherven, spetsialnyi vypusk. Kyiv, 163-165 (in Ukrainian).

Kravtsiv, R.I.,Ostapiuk, Yu.I., \& Kolishytskyi, Z.V. (2004). Hematolohichni pokaznyky molodniaka velykoi rohatoi khu-doby okremykh bioheokhimichnykh zon Zakhidnoi Ukrainy. Naukovyi visnyk Lvivskoi natsionalnoi akademii veterynarnoi medytsyny imeni S.Z. Hzhytskoho, 6(1), 188-191 (in Ukrainian).

Lazarenko, I.A., \& Melnykova, N.M. (2012). Kharakterystyka bilkovoho skladu krovi shchuriv, otruienykh svyntsem Biolohiia tvaryn, 14(1), 316-320. http://nbuv.gov.ua/UJRN/bitv_2012_14_1-2_51 (in Ukrainian).

Petrovska, M. (2011). Zdorovia naselennia Lvivskoi oblasti, yak rezultat reaktsii na zminy pryrodnoho seredovyshcha. Visnyk Lviv. UN-TU Seriia heohr, 39, 267-277. http://nbuv.gov.ua/UJRN/VLNU_Geograf_ 2011_39_31 (in Ukrainian).

Salvatori, F., Talassi, C.B., Salzgeber, S.A., Sipinosa, H.S., \& Bernardi, M.M. (2004). Embryotoxic and long-term 
effects of cadmium exposure during embryogenesis in rats. Neurotoxicology and Teratology, 26(5), 673-680. doi: 10.1016/j.ntt.2004.05.001.

Shevchenko, V.I., Novozhytska, Yu.M., \& Sakhniuk, V.V. (2004). Biokhimichni metody doslidzhennia krovi tvaryn: Metodychni rekomendatsii. Kyiv (in Ukrainian).

Stezhka, V.A., Dmitruha, N.N., Pokrovskaja, T.N., Bil'ko, T.A., \& Lampeka, E.G. (2003). K voprosu ob immuno-toksicheskom dejstvii soedinenij tjazhelyh metal- lov. Sovremennye problemy toksikologii, 1, 22- 29 (in Russian).

Vishchur, V.Y., Saranchuk, I.I., \& Gutyj, B.V. (2016). Fatty acid content of honeycombs depending on the level of technogenic loading on the environment. Vìsn. Dnìpropetr. Unìv Ser Bìol Ekol, 24(1), 182-187. doi: 10.15421/011622.

Vlizlo, V.V., Fedoruk, R.S., \& Makar, I.A. (2004). Fizioloho-biokhimichni metody doslidzhen $\mathrm{u}$ biolohii, tvarynnytstvi ta veterynarnii medytsyni. Dovidnyk. Lviv (in Ukrainian). 